\title{
PERAN PENGETAHUAN DAN INTENSI KEUANGAN TERHADAP PERILAKU MANAJEMEN KEUANGAN PADA MAHASISWA
}

\author{
Ekaningtyas Widiastuti
}

Manajemen

Fakultas Ekonomi dan Bisnis

Universitas Jenderal Soedirman

Email : widtyas@gmail.com

\begin{abstract}
ABSTRAK
Pengetahuan mengenai keuangan dan intensi bagi mahasiswa menjadi sesuatu yang menarik untuk dikaji dalam kaitannya dengan perilaku mahasiswa dalam mengatur keuangan yang dimiliki sehingga penelitian ini akan berusaha menelaah pengetahuan dan intensi keuangan ke perilaku keuangan mahasiswa. Sampel diambil dengan random dan sebanyak 100 mahasiswa Fakultas Ekonomi dan Bisnis Universitas Jenderal Soedirman berpartisipasi sebagai responden. Analisis data menggunakan regresi linier berganda dan menghasilkan perilaku manajemen keuangan mahasiswa FEB Universitas Jenderal Soedirman dapat dipengaruhi dengan positif oleh pengetahuan ataupun intensi keuangan baik secara parsial maupun simultan. Pengetahuan yang tepat dan dukungan dari niat dalam berperilaku sangat mendorong perilaku efektif dan efisien untuk mengelola dan mengambil keputusan keuangan dari mahasiswa FEB Universitas Jenderal Soedirman.
\end{abstract}

Kata Kunci: pengetahuan keuangan, intensi keuangan, perilaku manajemen keuangan

\begin{abstract}
Financial knowledge and intention for students is something interesting to study in relation to student behavior in managing their finances, so this study examines financial knowledge and intentions to student financial behavior. Samples were taken randomly and 100 students of the Faculty of Economics and Business, Jenderal Sudirman University participated as respondents. The data were analyzed by multiple linear regression and resulted that the financial management behavior of FEB students at Jenderal Soedirman University can be positively influenced by financial knowledge or intentions, either partially or simultaneously. The right knowledge and support from the intention to behave strongly encourage effective and efficient behavior to manage and make financial decisions from FEB students at Jenderal Soedirman University.
\end{abstract}

Keywords: financial knowledge, financial intentions, financial management behavior 


\section{PENDAHULUAN}

Perilaku manajemen keuangan merupakan suatu bentuk aplikasi konsepkonsep dalam manajemen keuangan yang mendasarkan pada konsep financial literacy. Saat ini topik terkait perilaku keuangan menjadi perhatian para akademisi dalam riset empiris dan literatur. Menurut Mien \& Thao, 2015 bahwa manajemen keuangan merupakan ilmu yang berhubungan dengan efektivitas manajemen dana sehingga menjadi sangat penting bagi suatu perusahaan.

Perilaku keuangan mewakili praktik individu dalam menggunakan uang tunai termasuk bagaimana mengelola tabungannya (Xiao, Tang, \& Shim, 2009). Merujuk pada temuan Xiao \& Wu (2006) dan Shim et al. (2010), perilaku individu pada keuangan diinginkan untuk meningkatkan kesejahteraan finansial. Perilaku yang dimaksud dapat mencakup pengelolaan uang tunai, kredit, tabungan, dan investasi sekaligus kesejahteraan finansial. Baik buruknya perilaku manajemen keuangan merupakan representasi dari tinggi rendahnya tingkat literasi keuangan yang dimiliki seseorang (Mien dan Thao, 2015).

Pengetahuan keuangan (financial knowledge) serta kemampuan individu untuk menghasilkan keputusan dan pengelolaan keuangan supaya lebih baik sering disebut literasi keuangan (Manurung dan Lutfi, 2009). Kemampuan dalam mengelola keuangan akan semakin baik jika pengetahuan tentang keuangan juga tingi. Achadiyah dan Laily (2014) dalam risetnya menemukan bukti perilaku manajemen dapat dipengaruhi positif terutama dengan pengetahuan keuangan. Artinya pengetahuan keuangan yang baik cenderung mendorong perilaku manajemen keuangan sesorang yang baik pula seperti memutuskan untuk melakukan investasi yang paling menguntungkan di masa mendatang. Sementara berbeda dari Kholilah dan Iramani (2013), Anugerah (2018) menyebutkan pengetahuan keuangan tidak berpengaruh terhadap perilaku manajemen keuangan.

Intensi mampu berpengaruh ke perilaku manajemen keuangan. Intensi keuangan adalah kehendak seseorang yang muncul sebagai penentu apakah seseorang tersebut akan melakukan atau tidak sesuatu yang bersangkutan dengan keuangannya. Menurut Zainiati (2017) seseorang akan bertindak sesuai dengan 
intensi yang dimilikinya. Ketika seseorang memiliki kehendak untuk menciptakan keamanan dan terjaminnya kondisi keuangan di masa mendatag, maka orang tersebut akan mengambil keputusan untuk melakukan investasi.

Permasalahan terkait dengan keuangan mahasiswa diantaranya adalah masih banyaknya golongan mahasiswa yang belum memiliki keterampilan keuangan dalam membuat perencanaan anggaran pengeluaran dengan baik karena tidak paham pentingnya penganggaran ini. Hasil penelitian Lestari (2015) menunjukkan bahwa mahasiswa FEB UNSOED yang well literate dalam hal keuangan tergolong rendah hanya sebesar 4,76\%, namun indeks utilitas produk dan jasa keuangan sebesar 95,24\%. Sementara itu, penelitian Ansong dan Gyensare (2012) menemukan mahasiswa fakultas ekonomi dan bisnis dibandingkan dari fakultas lain memiliki pengetahuan tentang keuangan yang lebih baik, dikarenakan kemungkinan telah diajarkan terkait manajemen keuangan di pendidikan formal dan mendapatkan materi dan pemahaman selama perkuliahan. Namun, penelitian Chen dan Volpe (1998) sebelumnya menyarankan perlunya penyelidikan tentang pengetahuan keuangan bagi mahasiswa manajemen keuangan. Berdasarkan permasalahan tersebut, artikel ini akan menganalisis aspek pengetahuan dan intensi keuangan dalam pengaruhnya ke perilaku manajemen keuangan khususnya mahasiswa Fakultas Ekonomi dan Bisnis.

\section{METODE PENELITIAN}

Responden akan dipilih dengan syarat mahasiswa angkatan 2016-2017 dan mengambil konsentrasi keuangan di FEB jurusan manajemen Universitas Jenderal Soedirman. Aspek pengetahuan keuangan memiliki indikator pengetahuan umum mengenai pengelolaan keuangan pribadi, pengeluaran dan pemasukan, mengenai tabungan, mengenai asuransi, dan investasi (Aprilia, 2015) sedangkan intensi keuangan dengan indikatornya rencana, tekad, janji (Zainiati, 2017). Variabel perilaku manajemen menggunakan indikator berupa perencanaan dan anggaran keuangan, cara penyusunan rencana keuangan, intensitas menabung, kegiatan asuransi, kegiatan kredit/hutang, evaluasi perencanaan keuangan (Amanah, 2016). 
Model penelitian yang akan diuji dapat digambarkan seperti berikut:

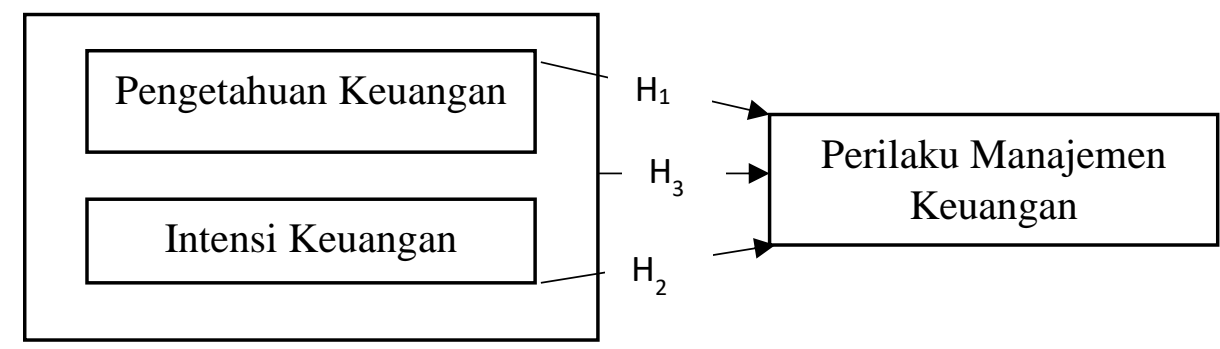

Gambar 1. Model Penelitian

Analisis pada gambar 1 akan merumuskan hipotesis penelitian seperti ini:

$\mathrm{H}_{1}$ : Perilaku manajemen keuangan dipengaruhi oleh pengetahuan keuangan pada mahasiswa FEB Universitas Jenderal Soedirman.

$\mathrm{H}_{2}$ : Perilaku manajemen keuangan dipengaruhi oleh intensi keuangan pada mahasiswa FEB Universitas Jenderal Soedirman

$\mathrm{H}_{3}$ : Perilaku manajemen keuangan dipengaruhi oleh pengetahuan dan intensi keuangan pada mahasiswa FEB Universitas Jenderal Soedirman

\section{HASIL DAN PEMBAHASAN}

Analisis yang dilakukan penulis mendapatkan bahwa hasil analisis terhadap data ada di Tabel 1. Tabel 1 menunjukkan persamaan regresi yang didapat adalah

$$
Y=12,865+0,177 X_{1}+0,270 X_{2}
$$

Persamaan tersebut menjelaskan bahwa baik pengetahuan maupun intensi memiliki dampak positif terhadap kemampuan manajemen keuangan di kalangan mahasiswa FEB Universitas Jenderal Soedirman. Dampak positif ini akan memberikan efek jika pengetahuan meningkat maka kemampuan manajemen keuangan pun akan meningkat. Jika intensi mahasiswa terdapat peningkatan maka peningkatan tersebut juga berlaku untuk kemampuan manajemen keuangan mahasiswa.

Kedua variabel yang diteliti memiliki nilai koefisien determinasi $\left(R^{2}\right) 0,428$ dan memperlihatkan godness of fit. Perilaku manajemen keuangan dapat dijelaskan sebesar $42,8 \%$ dari pengetahuan dan intensi. Sementara 57,2\% variabel yang 
berdampak pada perilaku manajemen tidak dianalisis di dalam model.

Tabel 1. Hasil Analisis Regresi Linear Berganda

\begin{tabular}{lrrr}
\hline \multicolumn{1}{c}{ Variabel } & B & t hitung & Sig. \\
\hline Constant & 12,865 & 9,153 & 0,000 \\
Pengetahuan $\left(\mathrm{X}_{1}\right)$ & 0,177 & 4,274 & 0,000 \\
Intensi $\left(\mathrm{X}_{2}\right)$ & 0,270 & 2,780 & 0,007 \\
\hline $\mathrm{R}^{2}$ & 0,428 & & \\
Sig. F & 0,000 & & \\
\hline
\end{tabular}

Pembuktian hipotesis yang diajukan dapat dilihat pada Tabel 1. t hitung untuk pengetahuan $\left(X_{1}\right)$ tercatat 4,274 dengan sig 0,000. Nilai ini menjabarkan bahwa pengetahuan mampu menjelaskan pengaruh positifnya ke perilaku manajemen keuangan secara parsial. Tingginya pengetahuan keuangan mahasiswa akan mendorong perilaku manajemen keuangan yang baik pula sehingga bahwa hipotesis yang diajukan diterima. Hasil ini didukung karena responden mahasiswa FEB Universitas Jenderal Soedirman merupakan mahasiswa dengan konsentrasi keuangan sehingga mereka sudah paham dasar-dasar dalam pengetahuan manajemen keuangan. Para mahasiswa memahami tujuan menabung dan cara menyimpan uang yang tepat dengan tujuan untuk kebutuhan masa depan, sehingga sebagian besar sudah memiliki tabungan dan ATM. Disamping itu, mereka telah mempelajari pengelolaan keuangan dengan mengikuti berbagai acara seperti seminar, workshop yang menambah pengetahuan mereka terkait dengan keuangan. Selain itu, mahasiswa juga belajar melalui media sosial atau internet bagaimana mengelola keuangan personal dengan tepat. Hasil yang didapat sangat selaras dengan Gutter (2008) yang menegaskan pengetahuan akan keuangan menjadi komponen penting yang membentuk perilaku keuangan dimana berkaitan dengan proses kognitif dan pemecahan masalah dalam mengambil keputusan. Humaira (2017) juga menemukan bahwa pengetahuan keuangan menentukan perilaku manajemen keuangan seseorang.

Uji t untuk intensi keuangan $\left(\mathrm{X}_{2}\right)$ menunjukkan 2,780 dengan sig 0,007 sehingga perilaku manajemen keuangan secara parsial dapat dipengaruhi dengan positif signifikan oleh intensi keuangan sehingga hipotesis yang diajukan diterima. Kondisi ini mencerminkan tingginya intensi keuangan maka berdampak baik pada 
perilaku manajemen keuangan mahasiswa. Sebagian besar mahasiswa Fakultas Ekonomi dan Bisnis Unsoed konsentrasi keuangan sudah memiliki rencana, tekad, kehendak untuk mengelola keuangan mereka, dan apa yang mereka lakukan sesuai dengan niatnya. Mereka telah mempunya niat untuk mulai menabung, belajar melakukan investasi melalui media sosial. Hasil penelitian mengindikasikan bahwa seseorang dengan baiknya intensi keuangan maka baik juga perilaku manajemen keuangannya. Hasil penelitian mendukung penelitian Zainiati (2017) yang menemukan bahwa seseorang akan bertindak sesuai dengan intensi yang dimilikinya, yaitu ketika seseorang mempunyai niat untuk menciptakan kondisi keuangan yang menjamin kehidupannya, akan mengambil keputusan pengelolaan dalam bentuk investasi.

Pengujian juga dilakukan secara simultan dengan melihat sig $\mathrm{F}$ yaitu 0,000 . Analisis ini mengambarkan perilaku manajemen keuangan mahasiswa dapat dipengaruhi aspek pengetahuan dan intensi secara bersama. Kondisi ini mengindikasikan bahwa pengetahuan yang dimiliki mahasiswa di bidang keuangan akan berdampak pada pola pikir tentang keadaaan keuangannya sehingga mengarahkan pada pengambilan keputusan serta penanganan keuangan yang strategis. Jika didukung dengan intensi atau niat dan tekad yang baik pula, maka kedua aspek tersebut akan sangat mendukung perencanaan, pengelolaan, bahkan pengambilan keputusan keuangan yang rasional dan tepat.

\section{KESIMPULAN DAN SARAN}

Proses analisis perilaku manajemen keuangan di kalangan mahasiswa FEB Universitas Jenderal Soedirman, menemukan kesimpulan :

1. Perilaku manajemen keuangan secara positif dipengaruhi oleh pengetahuan keuangan.

2. Perilaku manajemen keuangan secara positif dipengaruhi oleh intensi keuangan.

3. Perilaku manajemen keuangan mampu dipengaruhi secara simultan oleh pengetahuan dan intensi keuangan. 
Menambah indikator yang tidak diteliti seperti gaya hidup ataupun sikap keuangan bisa diarahkan untuk analisis lebih lanjut. Selain itu, dapat dianalisis pula komponen yang paling memberi pengaruh signifikan dalam pembentukan perilaku mahasiswa.

\section{DAFTAR PUSTAKA}

Achadiyah, B. N. dan Laily, N. (2013). Pengaruh Locus of Control Terhadap Hasil Belajar Mahasiswa Akuntansi. Jurnal Pendidikan Akuntansi Indonesia. 11. 1118. Diakses dari https://journal.uny.ac.id.

Amanah, Ersha. (2016). Pengaruh Financial Knowledge, Financial Attitude dan External Locus of Control terhadap Personal Financial Management Behavior pada Mahasiswa S1 Universitas Telkom. Skripsi. Fakultas Ekonomi dan Bisnis. Universitas Telkom. Bandung.

Ansong, A. dan Gyensare, M. (2012). Determinants of University Working Students' Financial Literacy at the University of Cape Coast, Ghana. International Journal of Business and Management. 7. 126-131. Diakses dari https://www.researchgate.net.

Aprilia, Zenika. (2015). Pengaruh Locus of Control, Financial Knowledge dan Personal Income terhadap Financial Management Behavior pada karyawan KPP Pratama Blitar. Skripsi. Fakultas Ekonomi dan Bisnis. Universitas Negeri Malang. Malang.

Chen, H. dan Volpe, R. P. (1998). An Analysis of Personal Financial Literacy Among College Students. Financial Services Review. 7. 107-128. Diakses dari https://econpapers.repec.org

Humaira, Iklima. (2017). Pengaruh Pengetahuan Keuangan, Sikap Keuangan, dan Kepribadian terhadap Perilaku Manajemen Kuangan pada Pelaku UMKM Sentra Kerajinan Batik Kabupaten Bantul. Skripsi. Fakultas Ekonomi dan Bisnis. Universitas Negeri Yogyakarta. Yogyakarta.

Kholilah, N. A. dan Iramani. (2013). Studi Financial Management Behavior pada Masyarakat Surabaya. Journal of Business and Banking. 3. 69-80. Diakses dari https://journal.perbanas.ac.id.

Manurung, Adler H. dan Lutfi, T. Rizky. (2009). Succesful Financial Planner : A Complete Guide. Jakarta: Grasindo. 
Mien, Nguyen Thi Ngoc dan Thao, Tran Phuong. (2015). Factors Affecting Personal Financial Management Behaviors: Evidence from Vietnam. Proceedings of the Second Asia-Pacific Conference on Global Business, Economics, Finance and Social Sciences (AP15Vietnam Conference).

Shim, S., Barber, B. L., Card, N. A., Xiao, J. J., \& Serido, J. (2010). Financial socialization of first-year college students: The roles of parents, work, and education. Journal of Youth and Adolescence, 39(12), 1457-1470. doi: 10.1007/s10964-009-9432-x.

Xiao, J. J., \& Wu, J. (2006). Applying the Theory of Planned Behavior of Consumers in Credit Counseling. International Journal of Consumer Studies, 30(2), 108-112.

Xiao, J. J., Tang, C., \& Shim, S. (2009). Acting for happiness: Financial Behavior and Life Satisfaction of College Students. Social Indicators Research, 92(1), 53-68. doi: 10.1007/s11205-008-9288-6.

Zainiati, Nia. (2017). Pengaruh Locus of Control dan Sikap Keuangan yang Dimediasi oleh Niat Terhadap Perilaku Pengelolaan Keuangan Keluarga. Skripsi. Fakultas Ekonomi dan Bisnis. Sekolah Tinggi Ilmu Ekonomi Perbanas. Surabaya. 